\title{
Financial Impact Assessment of Time Overrun: A Case of Second Small Towns Water Supply and Sanitation Sector Project, Nepal
}

\author{
Anjay Kumar Mishra ${ }^{1}$, \& P. S. Aithal ${ }^{2}$ \\ ${ }^{1}$ Associate Professor, Madan Bhandari Memorial Academy Nepal, Urlabari 3, Morang, Nepal \\ OrcidID: 0000-0003-2803-4918; Email: anjaymishra2000@gmail.com \\ ${ }^{2}$ Professor, College of Management \& Commerce, Srinivas University, Mangalore, India \\ OrcidID: 0000-0002-4691-8736; E-mail: psaithal@,gmail.com
}

Subject Area: Business Management.

Type of the Paper: Research Case Analysis.

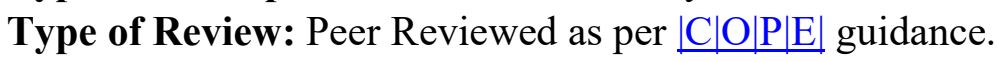

Indexed In: OpenAIRE.

DOI: $\underline{\text { http://doi.org/10.5281/zenodo. }}$

Google Scholar Citation: IJAEML.

\section{How to Cite this Paper:}

Anjay Kumar Mishra, \& Aithal, P. S. (2020). Financial Impact Assessment of Time Overrun:

A Case of Second Small Towns Water Supply and Sanitation Sector Project, Nepal International Journal of Applied Engineering and Management Letters (IJAEML), 4(2), 159173. DOI: http://doi.org/10.5281/zenodo.

International Journal of Applied Engineering and Management Letters (IJAEML)

A Refereed International Journal of Srinivas University, India.

(C) With Authors.

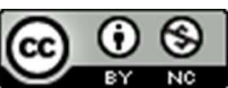

This work is licensed under a Creative Commons Attribution-Non-Commercial 4.0 International License subject to proper citation to the publication source of the work.

Disclaimer: The scholarly papers as reviewed and published by the Srinivas Publications (S.P.), India are the views and opinions of their respective authors and are not the views or opinions of the S.P. The S.P. disclaims of any harm or loss caused due to the published content to any party. 


\title{
Financial Impact Assessment of Time Overrun: A Case of Second Small Towns Water Supply and Sanitation Sector Project, Nepal
}

\author{
Anjay Kumar Mishra ${ }^{1}$, \& P. S. Aithal ${ }^{2}$ \\ ${ }^{1}$ Associate Professor, Madan Bhandari Memorial Academy Nepal, Urlabari 3, Morang, Nepal \\ OrcidID: 0000-0003-2803-4918; Email: anjaymishra2000@,gmail.com \\ ${ }^{2}$ Professor, College of Management \& Commerce, Srinivas University, Mangalore, India \\ OrcidID: 0000-0002-4691-8736; E-mail: psaithal@,gmail.com
}

\begin{abstract}
Government of Nepal is implementing many water-supply projects through its regular and through many projects. Small Town water Supply Project is one of the major projects in water supply implemented by GoN in support of ADB. Second Small Towns Water Supply and Sanitation Sector Project (STWSSSP) project is based on cost recovery principle. The study is focused to find out factors, magnitude, cost and the way time and cost overrun decreasing the profitability financially. All 21 sub projects are selected for study. The secondary data especially the requests by the Contractors, recommendations by Consultants and grants by Clients are used for the analysis of time and cost overrun. The financial evaluation of two projects is conducted after time and cost overrun to show the impacts of time and cost overrun in the profitability of the projects. The average time overrun of the overall projects are found 15.83 months with average time overrun of 11.58 months in Terai (plain land) located projects and 20.94 months in Hilly located projects. The sector project is found $10.68 \%$ increment in cost after variation with $9.33 \%$ in Terai located projects and $12.48 \%$ in Hill located projects. Financial profitability of the projects was found decreased due to time and cost overrun. The research concludes that project like SSTWSSSP which are based on the principle of cost recovery has significant impacts due to time and cost overrun. Because loan payment becomes delayed as tariff is only collected after completion of the project. It is therefore an equal role of Client, Consultants, Contractors and important stakeholders to foresee the probable factors of time and cost overrun and focus to reduce them.
\end{abstract}

Keywords: Cost Recovery, Cost Overrun, Terai, Hilly, Profitability

\section{INTRODUCTION:}

Project finishing on time and absence of cost overruns are considered the most important factors of successful projects, which help to decrease problems for all parties and give new chances to construct other related projects. Many construction projects including Road, Building, Irrigation, Hydropower and Water Supply in Nepal are subject to delay to the extent that it may extend to the $200 \%$ of time specialized for that project, resulting reduction of profitability, rise of cost and causing to technical and managerial issues among concerned. Cost overruns is also equally challenging issue, resulting slower project progress, as it causes the contractor a huge profit loss leaving the project in a big trouble.

Second Small Towns Water Supply and Sanitation Project (STWSSSP) was based on the principle of cost recovery where the users of the particular towns have to pay capital loan to Town Development Fund (TDF) within given maturity period. As Water is considered the basic needs, timely completion of Small Towns Water Supply and Sanitation Projects would be beneficial for community due to accessibility and timely collection of water tariff therefore, it is important to study the financial impact of time overrun of Second Small Towns Water Supply and Sanitation Projects.

Time Overrun is the main cause of Cost Overrun. The Sub Projects under Second Small Towns Water Supply and Sanitation Sector Project are spread particularly in Terai and Hilly regions all over the country. The time overrun in Terai region may not be similar to that of Hilly region. Therefore, this study is important to identify the financial impact based on region. 
Department of Water Supply and Sewerage has not the long experiences on contract administration that of other Departments as of Road, Irrigation, Building and Hydropower. Hence, this study will be beneficial particularly to Department of Water Supply and Sewerage for the contract administration of future water supply and sanitation projects lead by Department itself. For that it is of key importance to exert the utmost effort to accomplish such study, to detect the previously mentioned factors and to treat all the weakness points and from all sides and so giving specific priorities in order to avoid time and cost overruns at water supply and sanitation construction projects.

\section{OBJECTIVE:}

The research aims to identify the region wise (Terai and Hill) impacts of time and cost overrun in the Small Towns Water Supply and Sanitation Projects for pragmatic recommendation of cost recovery project implementation.

\section{LITERATURE REVIEW:}

\section{Project Time-Cost Relationship}

All out undertaking costs incorporate both direct expenses and roundabout expenses of playing out the exercises of the venture. In the event that every movement of the undertaking is planned for the span that outcomes in the base direct cost (typical length) at that point an opportunity to finish the whole venture may be too long and generous punishments related with the late task consummation may be acquired. As the immediate expense for the venture approaches the whole of the immediate expenses of its exercises, at that point the undertaking direct cost will increment by diminishing its term. Then again, the roundabout cost will diminish by diminishing the undertaking span. Following diagram shows the time cost relationship on venture cost.

Figure 1 shows the direct and indirect cost relationships with the project duration. The project total timecost relationship can be determined by adding up the direct cost and indirect cost values together. The optimum project duration can be determined as the project duration that results in the least project total cost. According to Menon et al., [1] proper planning of work, committed leadership and management, and effective communication system can be very helpful in improving time performance. In order to minimize the delays Suwal et al., [2] recommended following that (i) there should be provisions in PPA and PPR to control unusual low bid by increasing performance security as per percentage of bid below estimated amount, (ii) Appropriate contractors should be selected based on experience, technical, financial capacity along with consideration of work in hand. The provision of negative marking as per work in hand should be done in Public Procurement Act (PPA) and Public Procurement Rules (PPR), so that tendency of occupying works shall be reduced, (iii) Pre-execution preparation (such as land acquisition, utility relocation, EIA and IEE) and planning of project tasks, resource need and appropriate contract strategy to avoid low bid should be done, (iv) Strict provisions or limitation on project period variations should be done in PPA and PPR, (v) Proper mechanism should be built up for stable and fixed tenure of Project manager in the project, (vi) Efficient contract management by employer (quick decision and approval on time).

According to Mishra et.al. [4], The project time and cost of the Public Health Buildings projectsin Nepal was highly correlated $(\mathrm{p}=0.599)$. An equation, Time $=487.5 \times(\mathrm{C} / 79.96)^{0.293}$ (time is expressed in day and cost in million NRs.) was developed for the prediction of time and cost components of similar projects.

\section{METHODOLOGY :}

Study Area :

Department of Water Supply and Sewerage is implementing Second phase of second largest water supply project i.e, Second Small Towns Water Supply and Sanitation Project (STWSSSP) is selected for study availability of reports and documents during completion phase. All the twenty-one (21) sub projects of Second STWSSSP are spread over the country which helps region wise analysis of the projects as well. It project duration consists construction with 1 year of operation and maintenance. Consulting Services are provided through five different firms for design and supervision of these twenty one projects. Similarly, eight different contractors have been involved for the construction of the projects. Project Management Office (PMO) under the Department of Water Supply and Sewerage is the client of the project. Client, 
Consultant and the Contractors were interviewed mainly for key informants on cause factors of time overrun and suggestive success factors in order to lessen the cost and time overrun.

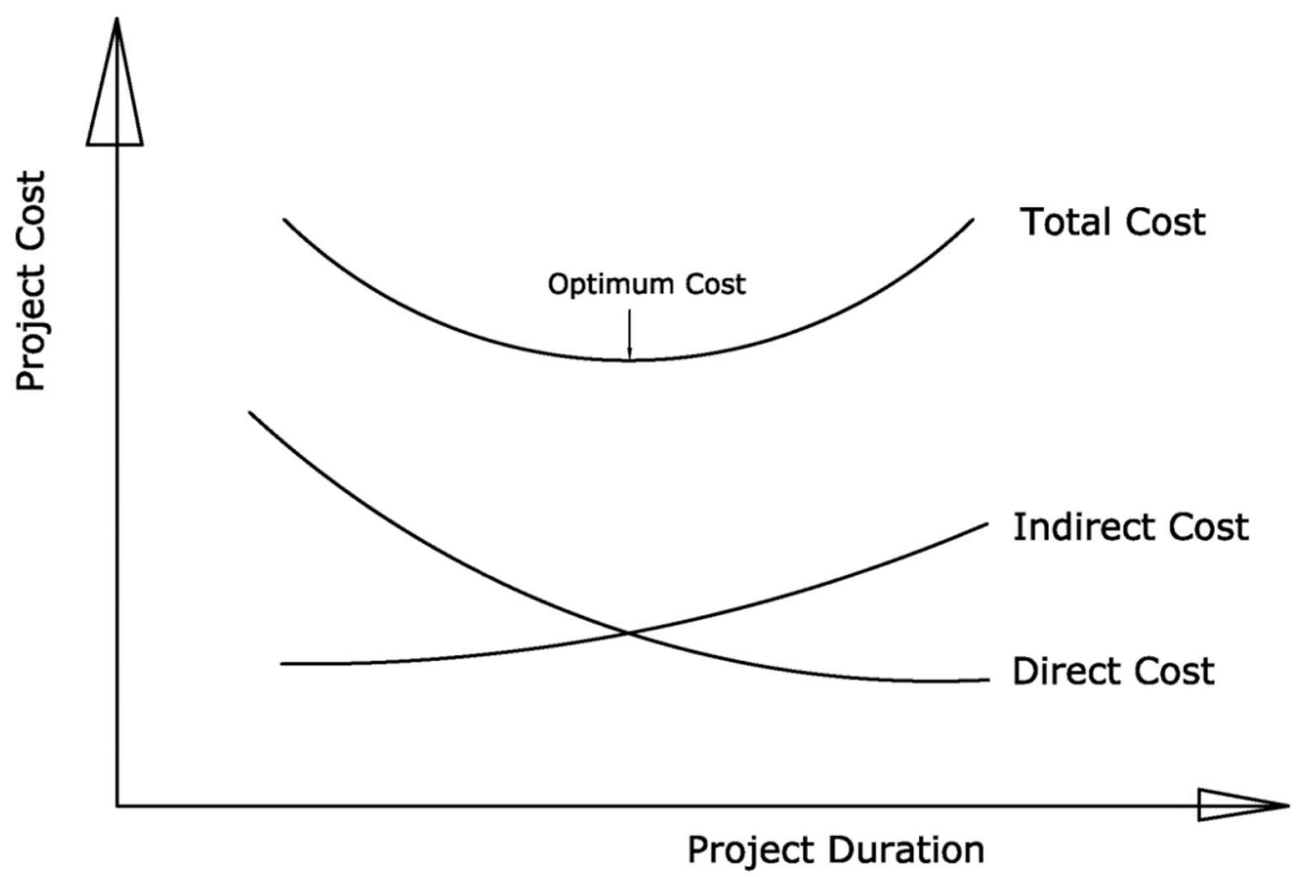

Fig. 1: Project Time-Cost Relationship (Komesh and Meenu, 2014 [3])

\section{Method of Data Collection}

Limited Consulting Firms and Contractors were engaged in the project, direct interview was taken aimed at obtaining preliminary data that would address the problems as identified and achieve the objectives. In order to achieve the objectives particularly on understanding the existing literature on critical success factors and identify the most recent studies regarding cost and time overrun, a systematic literature review was conducted. Books, Journals, Articles, Theses and dissertations and Internet became the source of information and considered to be an important factor when checking the validity of the information obtained.

Available data from Project Management Office was used to analyze the status of delays and price escalation of the sub projects under Second Small Towns Water Supply and Sanitation Sector Project. Similarly, the available reports, documents requesting for time extension and variations by the Contractors and Consultants helped finding out region wise different factors including the practices of granting the time extension and variation by the clients. More often, secondary data especially through the approved reports and documents were used to identify and analyze the various factors through Microsoft Excel to find frequency distributions causing delay and ranking of causes. Financial Analysis was done using Excel for two projects only.

\section{RESULTS AND DISCUSSION :}

\subsection{Time overrun of Projects}

Every project under Second Small Towns Water Supply and Sanitation Project (SSTWSSSP) has estimated construction time of 30 months including operation and maintenance by the contractor himself. The overall projects analysis shows that actual average time of the projects is 45.83 months. The average time overrun of the projects is 15.83 months with the ratio of 1.52 where as the Average increase in the cost of 10.68 $\%$ for all 21 projects. 
Table 1: Time-Cost status of the projects lied in Terai Belt

\begin{tabular}{|c|c|c|c|c|c|c|c|c|c|c|}
\hline $\mathbf{S N}$ & $\begin{array}{l}\text { Project } \\
\text { Name }\end{array}$ & \begin{tabular}{|l} 
Estimated \\
Time (mont
\end{tabular} & $\begin{array}{l}\text { Actual Tir } \\
\text { (month) }\end{array}$ & $\begin{array}{l}\text { Ratio } \\
\text { (t) }\end{array}$ & $\begin{array}{l}\text { Time Overr } \\
\text { (month) }\end{array}$ & Remarks & $\begin{array}{l}\text { Original } \\
\text { Contract } \\
\text { (MNRs) }\end{array}$ & $\begin{array}{l}\text { Contrac } \\
\text { AnAmt. a } \\
\text { Variatior } \\
\text { (NRs)) }\end{array}$ & $\begin{array}{l}\text { t } \% \\
\text { affincreases } \\
n \text { after } \\
\text { Variations }\end{array}$ & Remarks \\
\hline 1 & $\begin{array}{l}\text { Damak } \\
\text { SSTWSS } \\
\mathrm{P}\end{array}$ & 30 & 50 & 1.67 & 20 & $t>1$ & 272.8 & 284.2 & 4.17 & $\mathrm{c}>1$ \\
\hline 2 & $\begin{array}{l}\text { Duhabi } \\
\text { SSTWSS } \\
\mathrm{P}\end{array}$ & 30 & 50 & 1.67 & 20 & $t>1$ & 132.2 & 151.6 & 14.67 & $\mathrm{c}>1$ \\
\hline 3 & $\begin{array}{l}\text { Indrapur } \\
\text { SSTWSS } \\
\mathrm{P}\end{array}$ & 30 & 46 & 1.53 & 16 & $t>1$ & 185.1 & 206.6 & 11.61 & $\mathrm{c}>1$ \\
\hline 4 & $\begin{array}{l}\text { Mukunda } \\
\mathrm{r} \\
\text { SSTWSS } \\
\mathrm{P}\end{array}$ & 30 & 35.5 & 1.18 & 5.5 & $\mathrm{t}>1$ & 217.2 & 236.8 & 9.02 & $\mathrm{c}>1$ \\
\hline 5 & $\begin{array}{l}\text { Kakadvit } \\
\text { SSTWSS } \\
\mathrm{P}\end{array}$ & 30 & 30 & 1.0 & 0 & $\mathrm{t}=0$ & 310.7 & 339.9 & 9.39 & $\mathrm{c}>1$ \\
\hline 6 & $\begin{array}{l}\text { Letang } \\
\text { SSTWSS } \\
\mathrm{P}\end{array}$ & 30 & 35 & 1.16 & 5 & $t>1$ & 249.9 & 287.3 & 14.96 & $\mathrm{c}>1$ \\
\hline 7 & $\begin{array}{l}\text { Bhasi } \\
\text { SSTWSS } \\
\text { P }\end{array}$ & 30 & 41 & 1.37 & 11 & $t>1$ & 111.1 & 121.4 & 9.27 & $\mathrm{c}>1$ \\
\hline 8 & $\begin{array}{l}\text { Shivanag } \\
\text { SSTWSS } \\
\mathrm{P}\end{array}$ & 30 & 41 & 1.37 & 11 & $t>1$ & 152.6 & 166.8 & 9.30 & $\mathrm{c}>1$ \\
\hline 9 & $\begin{array}{l}\text { DarakSul } \\
\text { ad } \\
\text { SSTWSS } \\
\text { P }\end{array}$ & 30 & 53 & 1.76 & 23 & $t>1$ & 233.0 & 265.7 & 14.03 & $\mathrm{c}>1$ \\
\hline 10 & $\begin{array}{l}\text { Lamahi } \\
\text { SSTWSS } \\
\mathrm{P}\end{array}$ & 30 & 45.5 & 1.51 & 15.5 & $t>1$ & 145.9 & 164.0 & 12.07 & $\mathrm{c}>1$ \\
\hline 11 & $\begin{array}{l}\text { KaraiyaM } \\
\text { krahar } \\
\text { SSTWSS } \\
\text { P }\end{array}$ & 30 & 37 & 1.23 & 7 & $t>1$ & 93.1 & 98.6 & 5.9 & $\mathrm{c}>1$ \\
\hline \multirow[t]{2}{*}{12} & $\begin{array}{l}\text { Meghauli } \\
\text { SSTWSS } \\
\mathrm{P}\end{array}$ & 30 & 40 & 1.33 & 10 & $t>1$ & 174.2 & 170.1 & -2.35 & $\mathrm{c}<1$ \\
\hline & Average & \begin{tabular}{|l|}
30 \\
\end{tabular} & 42 & 1.39 & 11.58 & & & & & \\
\hline
\end{tabular}

The Table 1shows that the actual average time of the projects located in Terai(plain land) Belt is 42 months. The average time overrun of the projects is 11.58 months with the ratio of 1.39 where as cost increased percentage for Terai belt 12 projects were $9.33 \%$. 
Table 2 : Time-Cost status of the projects lied in Hilly Belt

\begin{tabular}{|l|l|l|l|l|l|l|l|l|l|l|}
\hline SN & Project Name & $\begin{array}{l}\text { EstimatedActual Tir } \\
\text { Time } \\
\text { (month) }\end{array}$ & $\begin{array}{l}\text { Ratio } \\
\text { (month) }\end{array}$ & $\begin{array}{l}\text { Time } \\
\text { Overru } \\
\text { (month }\end{array}$ & $\begin{array}{l}\text { Remarks } \\
\text { Original } \\
\text { Contract } \\
\text { Amt. } \\
\text { (MNRs) }\end{array}$ & $\begin{array}{l}\text { Contract } \\
\text { Amt. } \begin{array}{l}\text { afincreases } \\
\text { Variation } \\
\text { (NRs)) }\end{array}\end{array}$ & $\begin{array}{l}\text { Remarks } \\
\text { Variations }\end{array}$ \\
\hline 1 & Phidim SSTWSSSP & 30 & 59.5 & 1.98 & 29.5 & $\mathrm{t}>1$ & 151.9 & 174.2 & 14.68 & $\mathrm{c}>1$ \\
\hline 2 & Vyas SSTWSSSP & 30 & 48 & 1.6 & 18 & $\mathrm{t}>1$ & 239.5 & 254.3 & 6.17 & $\mathrm{c}>1$ \\
\hline 3 & Rampur SSTWSSSP & 30 & 50.5 & 1.68 & 20.5 & $\mathrm{t}>1$ & 243.4 & 264.0 & 8.46 & $\mathrm{c}>1$ \\
\hline 4 & Dhankuta SSTWSSSP & 30 & 33 & 1.1 & 3 & $\mathrm{t}>1$ & 229.8 & 264.0 & 8.96 & $\mathrm{c}>1$ \\
\hline 5 & Baitdi SSTWSSSP & 30 & 48.5 & 1.61 & 18.5 & $\mathrm{t}>1$ & 129.2 & 148.4 & 14.86 & $\mathrm{c}>1$ \\
\hline 6 & Khandbari SSTWSSS & 30 & 53 & 1.76 & 23 & $\mathrm{t}>1$ & 348.4 & 400.5 & 14.95 & $\mathrm{c}>1$ \\
\hline 7 & Narayan SSTWSSSP & 30 & 53 & 1.76 & 23 & $\mathrm{t}>1$ & 241.1 & 263.5 & 9.29 & $\mathrm{c}>1$ \\
\hline 8 & $\begin{array}{l}\text { Sandhikharka } \\
\text { SSTWSSSP }\end{array}$ & 30 & 51 & 1.70 & 21 & $\mathrm{t}>1$ & 108.4 & 130.1 & 20.01 & $\mathrm{c}>1$ \\
\hline 9 & Baglung SSTWSSSP & 30 & 62 & 2.06 & 32 & $\mathrm{t}>1$ & 185.3 & 213.1 & 15.00 & $\mathrm{c}>1$ \\
\hline & Average & $\mathbf{3 0}$ & $\mathbf{5 0 . 9 4}$ & $\mathbf{1 . 6 9}$ & $\mathbf{2 0 . 9 4}$ & - & - & - & $\mathbf{1 2 . 4 8}$ & - \\
\hline
\end{tabular}

The Table 2 shows that the actual average time of the projects located in Hilly Belt is 50.94 months. The average time overrun of the projects is 20.94 months with the ratio of 1.69 whereas average percentage increases of cost after Variations were $12.48 \%$. It should be specified the different at time scheduling.

\subsection{Major Factors Granted for Time and Cost Overruns by Clients}

Based on the reports, the causes of time and cost overrun of each project were analyses in the following table 3.

Table 3 : Factors of Time -Cost status of the projects

\section{Phidim, Panchthar Water Supply and Sanitation Project- Hilly Area}

\section{Time Overruns}

Delay due to Nepal Banda, Delay due to social conflict on construction of Intake, Government decision on closure of quarries and crushers, Delay due to additional works after variation, Delay due to excessive rainfall, land erosion, Delay due to festive season, Dashain and Tihar, Delay due to Terai Unrest and blockade and Delay due to massive Earthquake

\section{Cost Overruns}

Additional pipelines in missing toles/town areas, Dismantling of PCC and masonary works during laying of Pipes, Supply missing Pipe Fittings in BoQ, Supply missing Filter media in BoQ, Adjustment works of Flocculator, Additional House Connection works, Approach road to Intake and treatment plant, Construction of new 400 Cum Reservoir Tank, Additional compound wall and Additional admixtures for RCC

Damak, Jhapa Water Supply and Sanitation Project-Tarai
Delay due to additional pipe line works, GI Pipe Crossing, Brick masonry, Recreation Works (Recharge Pit) after variation, Delay due to Nepal Bandh, Delay due to unusual rainfall, Delay due to massive earthquake, Delay due to late payment, Delay due to holiday for CA election, Disturbances and delays due to closure of Quarries and Crushers, Delay in providing complete lists of households and Delay in providing the details of varied items
Additional pipeline works, GI Pipe Crossing works, Recreation and Recharge Pit, Fencing works over compound wall, Additional Pipe and Fittings missing in BoQ Construction of new Dosing Unit and Electrical Control Panel 


\section{Duhabi, Sunsari Water Supply and Sanitation Project-Tarai}

Delay due to sudden change in design of office building and pump house, Delay due to non-performance of newly constructed DTW and additional of new DTW, Delay in providing the site for storm water drainage work and delay in decision on making variation works final, Disturbances and delays due to unexpected rainfall, Delay due to Crisis of local materials, Delay due to Festival holidays and constitutional Assembly election, Scarcity of fuels, strikes and embargo problem and Delay due to varied items
Supply of missing Pipes and Fittings in BoQ, Repair and maintenance of existing OHT, RCC Cover Slabs for storm drains, Additional one storey office building ,Additional Boundary wall around deep tube well, Additional treatment unit, Construction of shed over Generator, Additional Pipeline Works, Additional Excavation due to occurrence of rock area, Additional quantity of sand and crushed gravelling for treatment unit, Additional cost over transportation of excavated material from $3 \mathrm{~km}$

\section{Indrapur, Morang Water Supply and Sanitation Project-Tarai}

Delay due to varied items (Recharge Pit, Additional Distribution Networks), Delay in decision regarding Landscaping and Plantation, NEA not providing the electricity line to the project in time, Non availability of House hold lists in time, Modification of Office Building, Delay due to late payment, Delay due to assembly election, Delay due to rain fall, Delay in Decision on sump well site and Unavailability of Materials
Construction of Recreational Pond (Recharge Pit), Supply of additional pumps for Electrical Treatment, Back Washing and Disinfection System, Supply of Bulk Meter, Supply of missing Pipes and Fittings in BoQ, Construction of Recreational Pond (Recharge Pit), Supply of additional pumps for Electrical Treatment, Back Washing and Disinfection System, Supply of Bulk Meter ,Supply of missing Pipes and Fittings in BoQ ,Additional Pipeline Works ,Fencing works over Compound Wall and Additional Pipeline Works and Fencing works over Compound Wall

\section{Mukundapur, Nawalparasi Water Supply and Sanitation Project-Tarai}

Delay due to Nepal Banda, Delay due to national election, Shortage of fuels, Delay due to approved varied items (stone masonry, fittings, pipes...),Delay in decision regarding Pressure filter, Sludge Drying Bed, Drainage
Construction of new meeting hall, Cost of landscaping, Construction of valve chambers, Supply and Installation of Ferrules and Saddles

\section{Vyas, Tanahun Water Supply and Sanitation Project-Hilly}

Delay due to massive earthquake, Delay in decision making/Instruction for site possession for public toilet, Septage treatment Plant, Gunadi Transmission Pipeline, Obstruction due to strikes (including Terai unrest, blockade and shortage of construction materials and fuels), Delay due to varied items (brick soling, PCC, Thrust Blocks in transmission mains),Filter media quarry stopped by DDC, Maintenance of existing transmission pipeline and Terai Unrest/Scarcity of fuel
Site Development works, Additional rock excavation for civil works, Brick soling, PCC, Supply of missing Pipe Fittings in BOQ, Construction of additional thrust blocks for transmission line of $250 \mathrm{~mm}$ dia DI Pipe, Additional Pipeline works including SSF, Additional Protection works, Additional room in office building, Excavation of Rock-encountered rocky area during construction of intake and collector well, Extra cost increase due to insurance cost increases on procuring vehicle, Additional HH Connections, Access Road and Reinforcements

Rampur, Palpa Water Supply and Sanitation Project-Hilly

Delay due to varied item of works, Terai unrest/Blockade/ Scarcity of fuels, Massive earthquake, Non availability of land for sludge drying bed, Delay in decision for providing site for drilling and additional new boring, Delay in Valve chamber \& Thrust Block design approval, Delay in approving Electrical poles and supply, Additional work on electrification, Disturbances at sites ,Shortage of sand and aggregates and Clarification on Fencing post $\mathrm{c} / \mathrm{c}$ distance
Supply of additional pies and Fittings due to revision of design, Additional Pipeline works, Construction of Dosing House/Compressor, Electric Panel Board House, Additional one floor of office Building, Breast Wall for Protection, Additional work on electrification, Deep tube well Boring, Electrification of building items and Change in construction materials on storm water drainage and all other variations 


\section{Dhankuta, Dhankuta Water Supply and Sanitation Project-Hilly}

Unavailability of Construction Materials (Sand, Aggregates), Delay due to assembly election 2070, Delay due to excessive rain, Delay to varied item of works, Delay due to Strikes/socio political issues, Massive Earthquakes, Pipe damage due to fire-pipe burnt at transmission line, Change of locations of construction pumping sites and Fine sand of the existing Slow Sand Filter needed changes for quality improvements

Supply and laying of additional Pipes and Fittings due to change locations of pumping mains and Civil works mainly for River training works/ Protection works

\section{Kakadvitta, Jhapa Water Supply and Sanitation Project;- Tarai,,only cost overrun}

Length of distribution pipe line increases to $9.8 \mathrm{~km}$ due to addition of new service area, Supply of additional pies and Fittings due to addition of service area, Additional House Connections, Additional Washout/ Valve Chambers, Additional Johnson type screen pipe, Additional storm water drain $(2 \mathrm{Km})$, Construction of new Assembly hall, Cost of Land development and Voltage Stabalizer.

\section{Letang, Morang Water Supply and Sanitation Project-Tarai}

Delay due to Strikes/ unavailability of construction materials, Rainfall and unseasonal adverse climate condition /Cold wave, Delay due to varied items (Pipelines/electromechanical parts),Delay due to Dashain, Tihar and Chath, Additional drilling depths in tube wells from 70 to 116, Delay due to Strikes/ unavailability of construction materials, Rainfall and unseasonal adverse climate condition /Cold wave, Delay due to varied items (Pipelines/ electromechanical parts), Delay due to Dashain, Tihar and Chath and Additional drilling depths in tube wells from 70 to 116.

Replacement of Submersible Pump and Voltage Stabilizers of higher capacity, Redesign of deep tube wells changes and increases electromechanical parts and accessories, Supply and Installation of Pipes and Fittings, Additional Gabion works and Supply and Installation of missing HDPE Saddles in BoQ and Generator Shed Construction.

Baitadi Water Supply and Sanitation Project-Hilly

Delay due to Strikes/ Nepal Banda/Blockade, Site possession, Decision making and design review of transmission pipeline, Submersible Pumps, and Thrust blocks, Delay in Payments, Delay due to varied items (Pipelines/ electromechanical parts, thrust blocks), Redesigning a new construction site for TP, Reservoir, Pump House due to non availability of land extend the time, Design review of the transmission Pipe lines, Massive Earthquake (Scarcity of Labor) and Testing and Commissioning.

\section{Bhasi, Kanchanpur Water Supply and Sanitation Project-Tarai}

Delay due to strikes, Delay due to varied items (Pipelines/ electrification works, public toilet, protection works...), Delay due to unavailability of Construction Material, Site Possession-household connections, surface drains and Delay in approval of water meter.
Replacement of Submersible Pump and Voltage Stabilizers of higher capacity, Redesigning a new construction site for TP, Reservoir, Pump House due to non availability of land changes the pipeline, Chlorination Dosing Unit, Supply, Laying and Jointing of additional Pipes and Fittings due to redesign of transmission pipelines, Site Development Works, Additional Thrust Blocks , Additional Stone masonry work due to less quantity in BoQ and Protection works for changed sites.
Supply, Laying and jointing of additional $14 \mathrm{~km}$ Pipelines and Fittings, Land Development and Landscaping, Construction of new public toilet, Construction of new meeting hall, Cost of electrification due to the change location of the high tension line, Tiling in the public toilet and Additional Gravel filling at DTW. 


\section{Khandbari, Sankhuwasabha Water Supply and Sanitation Project-Hilly}

Disturbance due to rainfall, Delay due to massive earthquake, Obstruction due to strikes (including Terai unrest and shortage of construction materials and fuels), Delayed decision making in DBST road crossing work, fire hydrant, valves, support blocks, pipe protection works, fire hydrants, crossing, household connections, Delay in site possession, Shortage of sand and gravel as government prohibited the extraction from Sabha, Arun, Hewaand Piluwa Khola, Delay due to varied additional works, Delay due to closure of quarries and crushers, Delay due to construction of access road, Disturbance due to damage of laid pipelines, Redesigning the location of Transmission Lineadditional pipe line and fitting, Rectification works on certain stretches of pipeline was damaged by road works.
Site Development works, Thrust Block construction, Supply, Laying and jointing of additional Pipelines and Fittings due to change in alignment, Increase Household connections, Rectification works on certain stretches of pipelines, Additional Cost for construction of access road, Increase the quantity of fire hydrants, DI, GI and HDPE fittings as per site condition, Additional Truss unit over treatment Plants, Additional compound wall, fencing, manhole cover due to missing and less quantity in BoQ and Dismantle and reinstate road pitches.

\section{Narayan, Dailekh Water Supply and Sanitation Project-Hilly}

Delayed decision making in changing the pipe material in transmission due to acidic nature, Delay due to varied Item of works including pipeline works due to change of pipes and fittings in Transmission main (site development, retaining structures), Delay due to redesign of pipe line, Strikes, Unavailability of construction materials and boarder blockade, Obstruction by locals to fulfill their different demands such as school building, irrigation scheme, Repair and reconstruction of pipeline and IC damaged due to widening of Dailekh Bazzar, Decision delay of office building, Site Possession-HH connections, Existence of rocky area in transmission main, Delay due to massive earthquake (shortage of materials) and Testing and commissioning.

Changed trench rate due to occurrence of BMS and Hard rock, Supply, Laying and jointing of Pipes and Fittings in distribution line, Due to rocky area in transmission pipe line additional work for wrapping pipe by glass wool and GI sheet and anchoring, Dismantle and Reinstate of existing black topped road, Retaining structure at Treatment Unit and Changes made in the pipe material in the transmission line, changes in the fitting and inclusion of concrete admixture.

\section{Shivanagar, Kailali Water Supply and Sanitation Project-Tarai}

Delay due to varied items (Additional Pipelines-15 km/ office rooms, electromechanical parts, Electricity main line and transformer installation work, Strike called by unqualified fighter, janajati, akhandasudurpaschim movement, Delay in approval of water meter, Delay in Payments, Delay in site possession- treatment plant, Site possession- public toilet, house connection, surface drain and Delay due to change location of DTW.
Supply, laying and jointing of Pipes and fittings missing in BoQ, Location change of Deep boring increases electrical transmission line, Additional Rooms in the Office Building, Porcelain tiling in Public Toilet, Additional Pipes and Fittings for Treatment Plant, pumping mains, Additional submersible pumps, HDPE for Drainage Works and DI Pipe for pumping main- due to change location of DTW and Gabion wall.

\section{DarakSukhad, Kailali Water Supply and Sanitation Project-Tarai}

Delay due to varied items (Additional Pipelines, new toilet, Supply, laying and jointing of Pipes and fittings meeting hall), Delay due to strikes, Non availability of construction materials, Dashain and Tihar, Delay due to not providing the lists of House hold connections, Site possessionSludge drying bed, Problems created during development of tube well delays treatment design, NEA delays supply of TOD meter , Treatment Plant- Design not done due to non-development of tube well and Deep Tube well depth increased to 250 against design of $150 \mathrm{~m}$. missing in BoQ, Additional Tube well and electromechanical works due to non-performance of early drilled tube well, New parking shed as per request by the WUSC, Additional sludge drying bed, Construction of new Meeting hall, One additional public toilet, Items purchase for Lab which were not in BoQ, Additional compound wall, Missing concrete work, metal works, Hume Pipes in BoQ and Increase depth of Deep Tube well. 


\section{Sandhikharka, Arghakhanchi Water Supply and Sanitation Project-Hilly}

Delay due to varied items (Additional Pipelines, new toilet, meeting hall),Delay due to strikes, Delay due to assembly election, Delay in mobilization payment, Delay in providing clarification and decision of DI pipes and fittings, Delay in finalization of new rates, Site possession-public toilet, Delay in payment, Rainfall and Adjudication.
Supply, laying and jointing of Pipes and fittings as request by WUSC and missing in BoQ, Protection work/Gabion wall, New Sand Washing Platform and Guard House, Increment the length of sewerage, Adjudication - Adjudicator's decision increases rate of gravel and sand ( method of measurement not clear in Specification), Dismantling and reinstatement of black topped road, $\mathrm{O} / \mathrm{M}$ period of vehicle is extended due to extension of project period and Increment in Transportation cost from quarry.

\section{Baglung Water Supply and Sanitation Project-Hilly}

Delay due to varied items ,Delay due to strikes (Nationwide and Baglung Banda),Scarcity of fuel, Unavailability of sand media sand for the roughening Filter, Disputes on house connection work, Delay due to additional work on existing roughening filter, Damage of laid pipeline during road construction by DoR, Delay in site possession of lab cum WUSC Building, Delay in site possession of Dudiya Intake CC and Transmission Line, Delay due to disturbances in Bhundi transmission pipe line, Delay due to not providing drawings and name list of household for connection work, Water meter (Delay in approval), Strikes by Crusher and mining association, Delay due to Payment, Delay due to massive earthquake, Delay in providing clarification and decision of DI Pipe and Fittings, Rainfall, Delay in decision to provide exact location of Rithe Treatment Plant, Delay in Finalization of New Rates, Delay due to assembly election and Testing and Commissioning.

Supply, laying and jointing of Pipes and fittings as request by WUSC and missing in BoQ, Excavation in rock-WUSC Building lies in rocky area, Additional quantity of sand and crushed gravel in treatment unit, Transportation cost of excavated material up to $3 \mathrm{~km}$, Additional $15 \mathrm{~mm}$ gate valve, New rate of Filter media due to change in specification for SSF, Thrust Block in Transmission mains and Distribution chambers in town areas.

\section{Lamahi, Dang Water Supply and Sanitation Project-Tarai}

Delay due to varied items, Delay due to strikes (Nationwide and Dang Banda), Unavailability of land- for electromechanical works, dumping site development, reservoir tank, drains, pipe line work, Monsoon, Electrical works-delay in approval by NEA, Delay in decision making by WUSC for remaining $\mathrm{HH}$ connections, Unavailability of site for drainage construction and Delay in approval of water meter.

Supply, laying and jointing of Pipes and fittings as request by WUSC and missing in BoQ, Additional Quantity of stone soling, Office Building, Additional compound wall due to availability of land, Road dismantles and reinstatement, Change generator location increases electrical work, $\mathrm{O} / \mathrm{M}$ of vehicle due to extension of project period, Site development work, Missing DI/GI Fittings and PP saddles and Additional Septic tank and incineration chamber.

KaraiyaMakrahar, Rupendehi Water Supply and Sanitation Project

Delay due to varied items (black top, public toilet, staircase in WUSC building, design change of electrification, tile work on toilet), Delay due to strikes, Unprecedented rainfall, Delay due to approval of water meter and Delay in payment.

Cost of Landscaping, Additional Cost for construction of Public toilet, Tractor on request of WUSC, Missing DI/GI fittings and PP Saddles, Shades for generator house and revenue counters, dismantling of concrete footpaths, Access road, pitch cutting and re-pitching, Replacement of submersible pumps and Additional cost of electrical works due to redesigning.

\section{Meghauli, Chitwan Water Supply and Sanitation Project- Tarai, only Time overruns}

Conflicts among Users on House connection using clamps or tee, Delay due to availability of land for pipe laying in town area, Delay due to varied items (additional pipeline works), Delay in decision making by users on House connection, Delay due to strikes, Delay due to approval of water meter and Site possession-storm drain.

Both Extension of Time and Variation Order were being granted on the basis of request by Contractors, recommendation by DSC and further recommendation by PMC based on Time Extension clause (26) of GCC and clause 120(3) [5] of Public Procurement Regulation 2064 [6] without Compensation with extension of Performance Bond without Price adjustment during EoT after verification based on supporting documents, i.e., Users minutes, minutes of the Project Management Meeting and Evidences, It 
was additional works demands by the Users and initially missing items in BoQ were the main reason for VO where Provision for Price Adjustment, contingencies had not been included in the VO with a proper Line of Communications i.e. VO/EO submitted by Team Leader to Client/Authorized Representative. VO granted based on clause 54 (1) of Public Procurement Act 2063 and 118(1) of Public Procurement Regulation 2064 [7] including with Condition of Contract of the Contract Document. In some cases, the review of Procurement Experts were taken prior recommending/granting EOT and VO and Many requests for EoT and $\mathrm{VO}$ were being resubmitted due to lack of sufficient documents on recommendation by PMC with comments.

The factors of Time overrun were given during interview as checklist based on modified checklist of Yadav and Mishra [8] \& Ghimire and Mishra [9] for building and Hydropower respectively asked regarding the presence and absence to verify the documents authenticity and based on frequency; it is presented in figure 2 for Hilly area projects. In Hill located SSTWSSSP projects, social disputes at source and disturbances during construction was one of the major causes of time extension including other causes of delay as variations, strikes, rainfall, earthquake and decision delay.

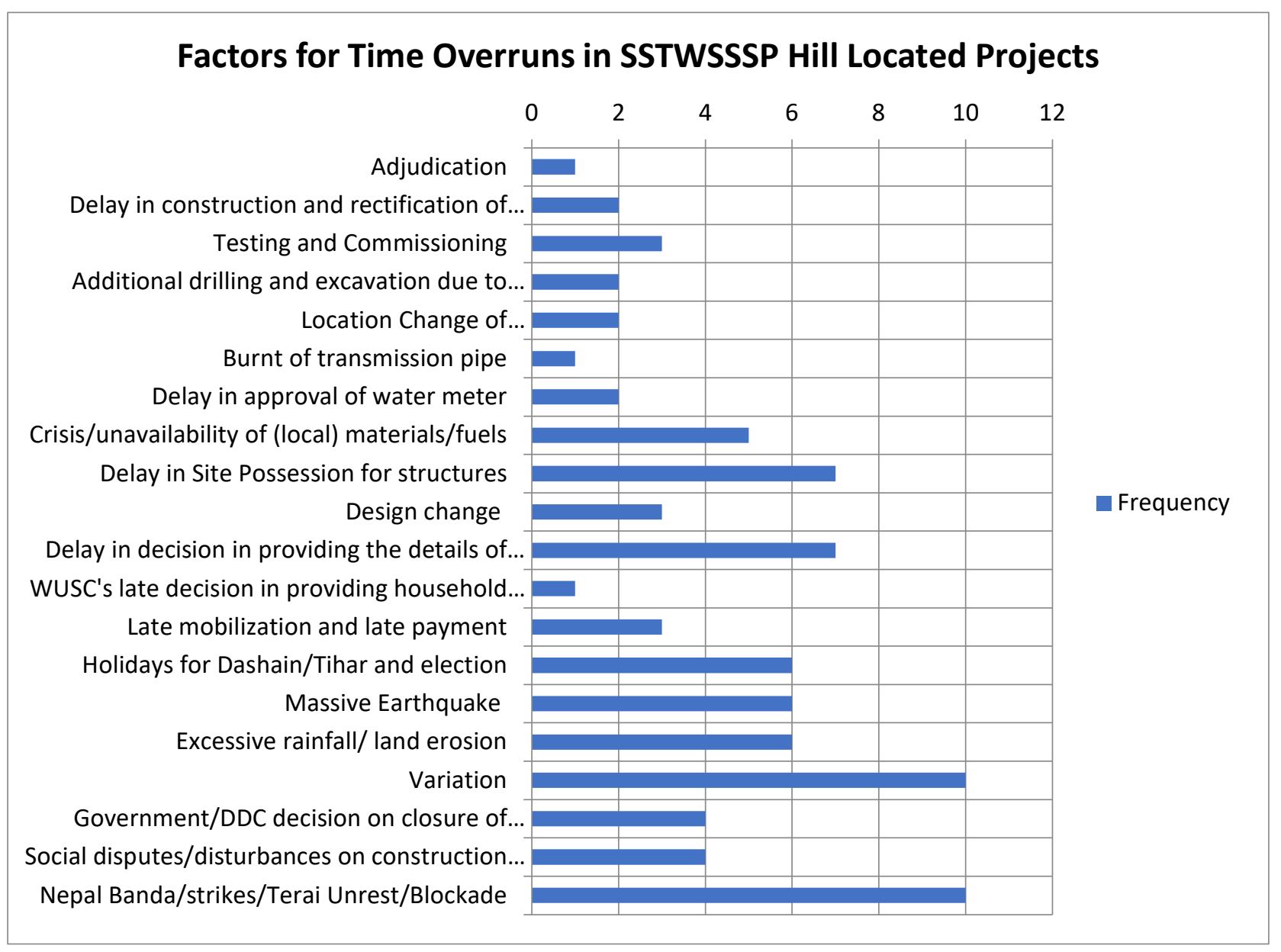

Fig 2: Causes of Time Overrun in Hill Located projects

Government/DDC decision to closure of quarries and crushers affected mostly to the hill located projects. The other causes factor of time extension in the hill located projects were adjudication, accident (pipe burnt) and massive earthquake. The rectification of the damaged pipe lines that were laid already due to construction of road became one of the causes of time extension. Similarly, for Tarai area project refer Figure 3. In Terai located SSTWSSSP projects, except the common cause factors such as variations, strikes, rainfall, earthquake and decision delay, the NEA's late approval of providing electricity line to the project was the main cause of time extension. 


\section{Factors for Time Overruns in SSTWSSSP Terai Located Projects}

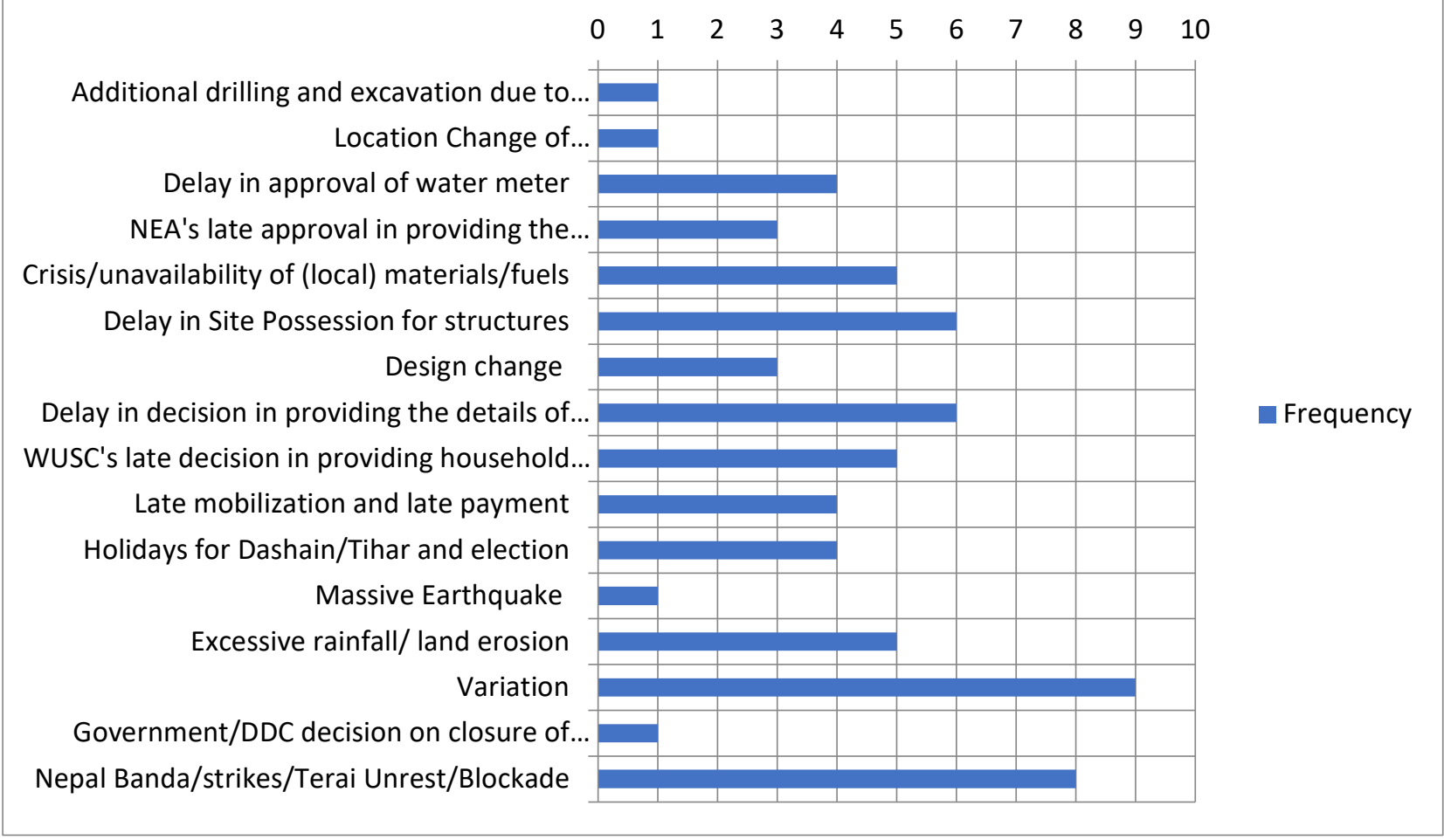

Fig 3: Causes of Time Overrun in Terai Located projects

Extension of pipe line works and construction of office buildings for WUSC were among the main variation works followed by supplying of missing pipe fittings. Nepal Bandh/strikes including terai unrest and blockade had been reported as another cause factor for time extension. The consequences of the strikes creating unavailability of the construction materials and fuels was been granted by the clients as a cause factor of time extension. Delay in decision by the consultants in providing the details of varied items/ sludge drying/pressure filter/ transmission line/storm drains/drilling etc., was also the major factor of time extension. This is followed by the delay in site possession by the clients and representative of the client, the WUSC. Excessive rainfall, massive earthquake and the series of aftershock that occurred on $25^{\text {th }}$ April 2015 where been the causes for time extension of the project. The consequences of the earthquake as scarcity of manpower, materials were being reported in some of the town projects where the effect was minimal.

Timely unavailable of the household lists from the respective WUSC of the town project was became one of the causes of the time extension for various project. Similarly, late approval of water meter by the consultant extends the time for many projects. NEA's late approval of providing electricity line to some of the projects had also been the cause of the time extension. Unforeseen site conditions such as drilling works and occurrence of rocky area during laying of pipes took extra time for completing those works. Design change, change of location for construction, Dashain/ Tihar and Election Holidays, Late payments, adjudication and burnt of pipes at site were also granted as a cause for time extension in some projects. The frequency of these factors is less than the factors described above. In the same way, figure 4 shows the factors of cost overrun.

Fig 4 shows the major factors of cost overrun in STWSSSP projects. Ten factors had been identified so far for granting variations by the client upon request by contractors and recommendations by consultants. Additional works mainly including additional laying of pipelines, sheds, treatment plants, and structures comes as a major factor of cost overrun followed by missing items in BoQ mainly as pipe and pipe fittings as a second major factor. Many items upon request of WUSC such as construction of office building, public toilet had been incorporated as a third major factor of cost overrun in the project. Cost had been increased also upon additional activities due to change in the location than estimated mainly in electrification works and additional works upon unforeseen ground condition comes as fourth and fifth major factor. Increased 
cost due to client's lost in adjudication had increased cost of some projects. Similarly change in the materials than estimated and increased cost due to extension of time such as transportation, insurance also been granted for cost variations.

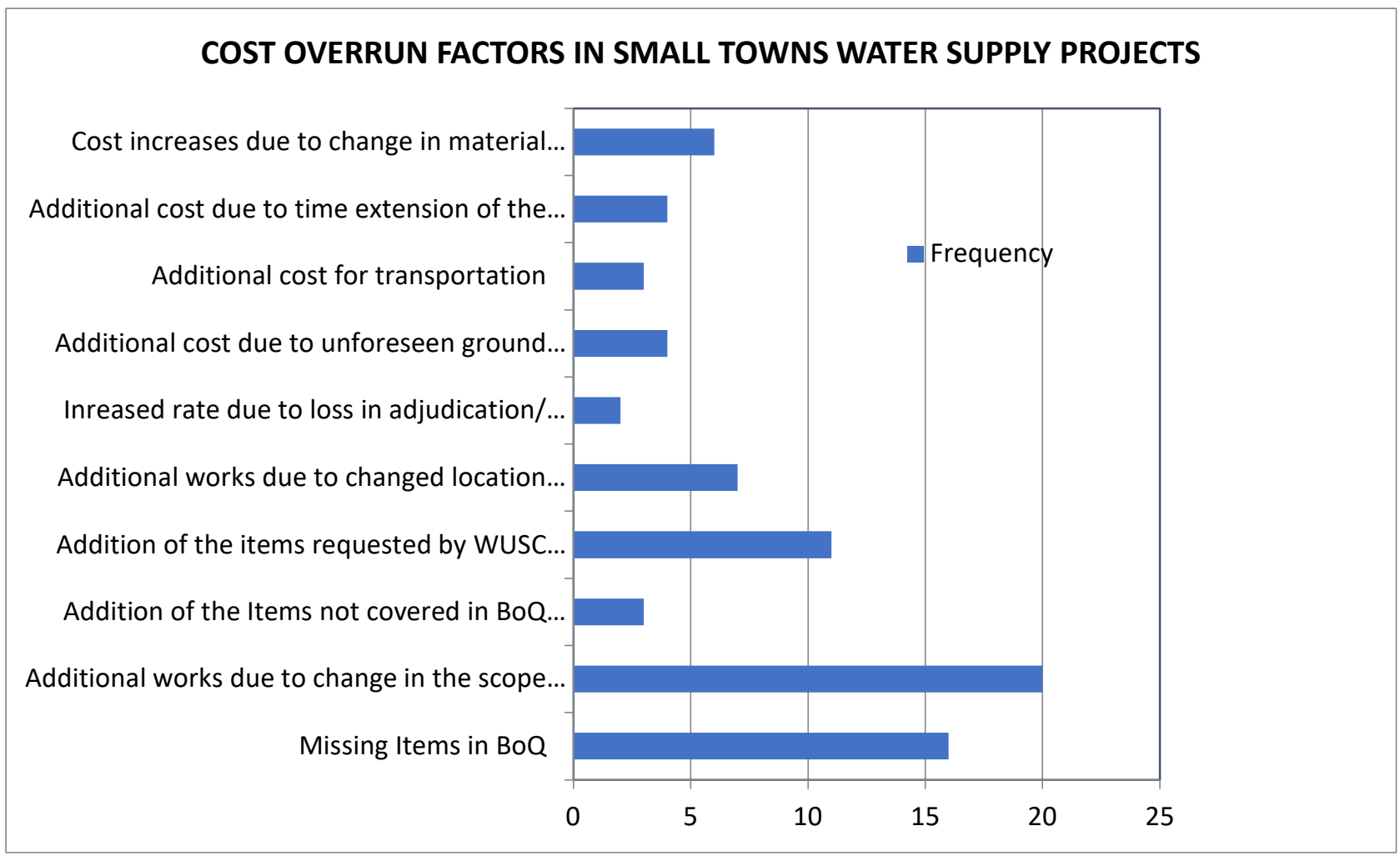

Fig 4: Cause Factors of Cost Overrun in STWSSSP Projects

During Key Informant Interview (KII), consultant's professionalism was the major factor of time and cost overrun in the eyes of clients and contractors because many projects were delayed due to late decisions and approval. In many projects design had been changed and there were lots of mistakes in the previous design. These were the major factors for the overruns. The provisions of performance evaluation of the consultants and the decisions there after have not been accepted. The provision of professional liability seems less in the contract document. The second major factor accepted by all three parties was strikes (Bandh) and all suggested the political stability can stop all types of strikes. Contractor's financial capacity had been viewed by client and consultants as another major factor of delay because the contractor's involvements in many projects have an effect in the regular cash flow. Due to this the contractor could not pay to the labors and market in time and delayed the particular project. The lack of coordination and lack of timely decision due to the involvement of many stakeholders and low bid of the project were also considered major factors by the clients.

Similarly, slow decisions by the clients in order to provide grant to EoT and Variations, WUSC's unusual demands during implementation of the project and Improper plan and management of the contractor were regarded as major factors of delay by the consultants. Quantity overrun due to various reasons like expansion of pipelines, WUSC's unusual demands, and changed scope of the project was taken as a major factor by Contractor. Delay in site possession by clients (WUSC) and Social Conflicts at source, HH Connections, pipelines were also considered as a major factor by Contractors.

\subsection{Financial Impact of Time Overrun on Projects}

Phidim and Mukundapur Town Projects have been evaluated as a represents of remaining town projects from Hilly and Tarai Area in table 4. 
Table 4: Financial Evaluation of project after Time Overrun

\begin{tabular}{|c|c|c|c|c|c|c|c|}
\hline \multicolumn{4}{|c|}{$\begin{array}{l}\text { Phidim Town Water Supply and Sanitation } \\
\text { Project }\end{array}$} & \multicolumn{4}{|c|}{$\begin{array}{l}\text { Mukundapur Town Water Supply and } \\
\text { Sanitation Project }\end{array}$} \\
\hline SN & Parameters & Estimated & $\begin{array}{l}\text { After } \\
\text { Time and } \\
\text { Cost } \\
\text { Overrun }\end{array}$ & SN & Parameters & Estimated & $\begin{array}{l}\text { After } \\
\text { Time and } \\
\text { Cost } \\
\text { Overrun }\end{array}$ \\
\hline 1 & FIRR & $3.28 \%$ & $2.89 \%$ & 1 & FIRR & $3.28 \%$ & $2.89 \%$ \\
\hline 2 & AIFC & 29.1 & 29.1 & 2 & AIFC & 29.1 & 29.1 \\
\hline 3 & EIRR & 38.73 & 31.46 & 3 & EIRR & 38.73 & 31.46 \\
\hline 4 & AIEC & 40.06 & 41.96 & 4 & AIEC & 40.06 & 41.96 \\
\hline
\end{tabular}

Above table 4 clarifies that the time and cost overrun decreases the profit margin of project both financially and economically. Due to increase in time of 29.5 and 5.5 months and cost of $14.68 \%$ and $9.02 \%$ respectively of Phidim and Mukundapur Town Projects, FIRR and EIRR of the projects are highly decreases. Similar results were found in Hydropower projects by Chiluwal and Mishra [10]. AIFC (Average Incremental Financial Cost) which is used to determine financial tariffs required to achieve full cost recovery and the level necessary to achieve recovery of O\&M costs and debt payments is increased. Similarly, AIEC (Average Incremental Economic Cost) which is the present value of all the economic capital investments and economic operating costs throughout the project life divided by the total water produced over the period as expressed economic cost per cubic meter of water produced also increased. All the remaining town projects have cost or time overruns or both. Thus, the profit margin of the remaining projects decreases as well.

\subsection{Recommendations}

All three parties, Client, Consultant and Contractor are equally responsibly for time and cost overrun.

\section{Client/Developer/Government}

- Client should prepare the project well before implementation with proper detail study, design and engineering by including all stakeholders from the beginning.

- Client should allocate sufficient budget for project implementation and as well to social welfare and environmental mitigation and make good relation with neighbour and society.

- Client should evaluate the performance of the consultant at different stages and make consultant liable at all the mistakes concurred by consultant.

- Client should impose realistic contract duration and requirements.

- Client should possess the site of construction before making agreement with Contractor.

- Government shall categorize the contractors based upon their work experiences and allow only the particular experienced contractor for the project.

- There should be provisions in PPA and PPR to control unusual low bid by selecting second or third lowest bid as practiced in other countries.

\section{Consultant}

- Pre-execution preparation (such as land acquisition, utility relocation, EIA and IEE) and planning of project tasks, resource need and appropriate contract strategy to avoid low bid should be done.

- Prior to tendering and subsequent awarding of contracts, consultant should make available of adequate and comprehensive documents. Such documents should be adequate in terms of the initial analysis of costs, scope of works to be executed and the expected duration.

- The Consultant should have well knowledge on contract administration, and should ensure that the monsoon and festive holidays are managed in work schedule through local calendar and resource planning.

\section{Contractor}

- Contractor should make proper planning and management of required qualified and quantified technical staffs and construction materials

- Contractor should make advance purchase agreement the probable incidents in order to avoid shortage or lack of fuel and materials. 


\section{CONCLUSIONS:}

All the projects under Second Small Town Water Supply and Sanitation Projects selected for study are time overrun. Due to the active participation and involvement of respective Users' Committee, the time overrun of the projects are found quite less than the government's solely implemented project. Variation, Social issues like Bandhs, strikes and disputes, Delay in decision, site possession and natural calamities are found the major factors in delaying the implementation of water supply projects under SSTWSSSP projects.

Lack of consultant's professionalism, Contractor's financial capacity, involvement many stakeholders, Low bid by the contractor, improper planning and management of Contractor, WUSC's unusual demands are the factors for delay of implementation through view of Client and Consultant. Similarly, quantity overrun, Lack of consultant's professionalism and social conflicts are the major factors of delay in the eye of Contractors.

Similarly, the factors responsible for the cost escalation in construction of small town water supply projects under request of Contractors, recommendations by Consultants and grant by Clients are categorized as Additional works due to change in the scope of the project, Missing items in BoQ, Additional items demanded by WUSC, Additional works due to changed location, Change of the material, Unforeseen ground condition, Additional works due to time extension of the project and Adjudication. Financial and economic indicators such as FIRR and EIRR decrease as time of construction increases the operating period of the project decreases. The other factor significantly reduces the financial and economic factor is cost escalation in the project. Due to time and cost overrun the financial and economic parameters FIRR, EIRR and NPV all decreases which reduce the profitability of project. But the projects are still profitable.

Acknowledgements:

I would like to express my deepest thanks to all the helping hands without which this work would not have been completed. This research is dedicated to all the people affected from COVID19 and hope the world is going to come over this problem. A great salutation to health professional.

\section{REFERENCE :}

[1] Memon, A. H., Rahman, I. A., Akram, M., \& N. Md. (2014). Significant Factors Causing Time Overrun in Construction Projects of Peninsular Malaysia. University Tun Hussein Onn Malaysia, Malaysia.

[2] Suwal, A., Shrestha, S. K. (2016). Causes of Delays of Motorable Bridge Construction Under Postal Highway Projects, Departments of Roads. Journal of Advanced College of Engineering and Management, 2(1), 85-92.

[3] Mishra, A. K., Sudarsan, J. S. \& Nithiyanantham, S. (2020). Assessment of time-cost model of public health buildings in Nepal. Asian J Civ Eng. 1-10. https://doi.org/10.1007/s42107-020-00294-4.

[4] GoN, Standard Bidding Document; Procurement of Works, January 2009. Public Procurement Monitoring office (PPMO), Tahachal, Kathmandu, Nepal.

[5] GON, Public Procurement Act, 14 January 2007.

[6] GON, Public Procurement Regulation, 20 August 2007.

[7] GON, Procurement Act Amendment, 2016.

[8] Yadav, S. K., \& Mishra, A. K. (2019). Status of Time and Cost Overrun of Health Building Construction Projects in Nepal. Sch J Eng Tech, 7(9), 262- 270. DOI: 10.36347/SJET.2019.v07i09.003.

[9] Ghimire, S. \& Mishra, A. K. (2019). Comparative Study of Prospective Delay Analysis Techniques (DATs). Saudi J Civ Eng., 3(5), 84-95. DOI:10.21276/sjce.2019.3.5.1.

[10] Chiluwal K. and Mishra A. K., (2018). Impact of performance on profitability of small hydropower projects in Nepal. International Journal of Current Research, 10(01), 63918-63925. 